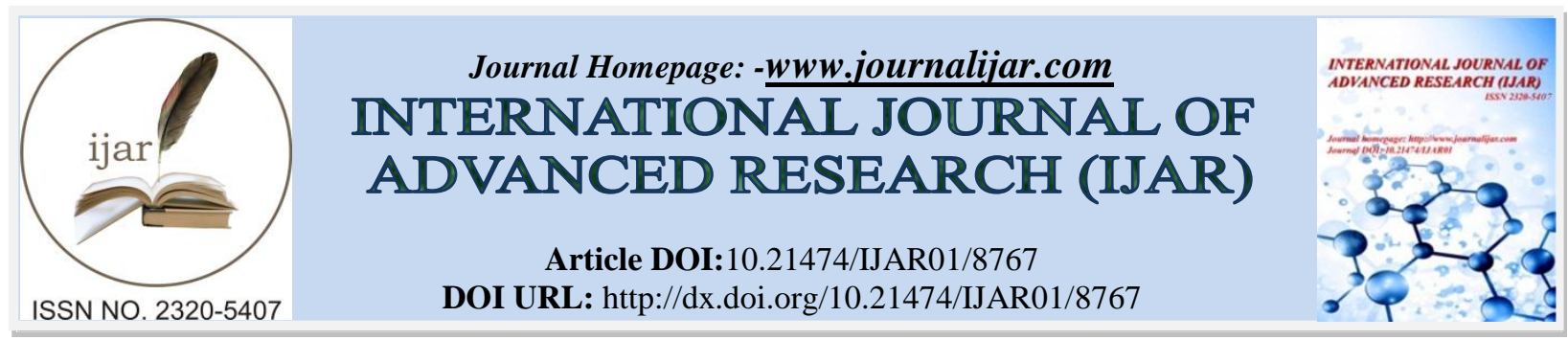

RESEARCH ARTICLE

\title{
BACTRODESMIUM AQUATICA SP. NOV. (MITOSPORIC FUNGI) ON SUBMERGED WOOD FROM FRESHWATER, MAHARASHTRA, INDIA.
}

Borse B. D. ${ }^{1}$, N.S. Pawar ${ }^{2}$ and S. Y. Patil ${ }^{3}$.

1. N.S. S. Dhule's U. P. Arts and Science College, Dahiwel, Dhule, M. S.

2. S.S.V.P. S.'s Arts, Comm. and Sci. College, Shindkheda, Dhule, M. S.

3. S.S.V.P. S's L. K. Dr. P. R. Ghogrey Science College, Dhule, M. S.

\section{Manuscript Info}

\section{Manuscript History}

Received: 20 January 2019

Final Accepted: 22 February 2019

Published: March 2019

Key words:-

Freshwater, mitosporic fungi, submerged wood, taxonomy.

\section{Abstract}

A new species of Bactrodesmium, B. aquatica, was collected from northern parts of Western Ghats on submerged herbaceous and woody debris from freshwater streams and reservoirs in Maharashtra and is described. The new submerged-aquatic hyphomycetous fungus is differed from the related species of the genus in size and characteristics of sporodochia and conidia.

Copy Right, IJAR, 2019,. All rights reserved.

\section{Introduction:-}

The submerged-aquatic hyphomycetes were first addressed by Ingold (1975) represent a heterogenous assemblage of fungi growing on submerged decaying plant materials. Most of the species are found on woody litter blocked in fast-flowing streams and reservoirs. These fungi are nearly all dematiaceous and produced relatively thick-walled conidiophores and/or conidia. Although some species may sporulate under submerged conditions, a vast number sporulate when the substrate are no longer under water. Incubation of such woody substrates in moist chambers yields a great number of different species. The conidia are capable of air dispersal or dispersed by some other mechanisms (Goh \& Hyde 1996). The submerged-aquatic hyphomycetes can be classified into two main types based on Park (1972), namely indwellers and immigrants. Species in several genera e. g Aquaphila, Camposporidium and Canalisporium etc. can be classified as indwellers because they have been reported only from freshwater habitats. Whereas, species that belong to genera such as Acrodictys, Bactrodesmium, Vanakripa, and Xylomyces etc. can be classified as immigrants because they are reported from terrestrial as well as freshwater habitats. Goh \& Tsui (2003) This paper provide a key to some common genera of dematiaceous mitosporic fungi that have been reported from freshwater habitats worldwide.

\section{Materials \& Methods:-}

Samples of submerged decomposed herbaceous and woody debris were collected from rivers and reservoirs. The samples were returned to the laboratory keeping in plastic bags in the field and immediately examined with a dissecting microscope to locate fungal fruiting bodies. After the first observation, samples were incubated for three months on a moist paper towels in sterile plastic boxes at ambient temperature of $25^{0}-30^{\circ} \mathrm{C}$ to stimulate fungal development. Incubated samples were examined on $15^{\text {th }}$ day and then over three months under a dissecting microscope for fungal fruiting bodies. Sporodochia were observed on the surface of the substrate with the naked eye and under a stereo-zoom microscope. Sporodochia and conidia were mounted in lactic acid with cotton blue and measured using an ocular micrometer with 25 observations per structure. The holotype specimen (slides) is 
deposited in the Herbarium Cryptogamie Indiae Orientalis (H.C.I.O.), Division of mycology and plant Pathology, I.A.R.I. Pusa Campus, New Delhi, India (HCIO 52065).

\section{Taxonomy}

Bactrodesmium aquatica Borse, S.Y. Patil \& N.S. Pawar, sp. nov. Fig. 1-2

MycoBank No: MB 830028

TYPE: India, Maharashtra, Nakana dam, Dhule. On submerged dead decaying herbaceous and woody debris, 15 August 1999, B. D. Borse (Holotype, HCIO 52065).

ETYMOLOGY: referring from the Latin aquaticus meaning 'growing in water'

\section{Diagnosis:}

Colonies on submerged herbaceous and woody debris in freshwater habitats. Sporodochia scattered, black, compact, shining, $100-500 \mu \mathrm{m}$ in diam., surrounded by $25-40 \mu \mathrm{m}$ thick gelatinous matrix; Conidiophores fasciculate, branched, hyaline, septate. Conidia broadly pyriform, curved, rounded at the apex, 15-25 $\mu \mathrm{m}$ high, 10-15 $\mu \mathrm{m}$ diam, 2-septate; black band at the septa, apical cell subglobose, brown, 15-26 $\mu \mathrm{m}$ high, 13-18 $\mu \mathrm{m}$ in diam.; middle and lower cells obconical and subhyaline, frequently curved.

\section{Description: Colonies:}

On natural substratum (submerged herbaceous and woody debris in freshwater habitats) in the form of sporodochia. Sporodochia: scattered or clustered, black, compact, shining, 100-500 $\mu \mathrm{m}$ in diam., surrounded by 25-40 $\mu \mathrm{m}$ thick gelatinous matrix; matrix composed of nodulated, non-septate, branched hyphae-like elements. Conidiophores: fasciculate, ascending to erect, branched, hyaline, thin-walled, and septate. Conidia: broadly pyriform, curved, smooth-walled, gattulate, rounded at the apex, 15-25 $\mu \mathrm{m}$ high, 10-15 $\mu \mathrm{m}$ diam, 2-septate; thin brown to black band at the septa, slightly constricted at the septa, cells dissimilar; apical cell subglobose, brown, 15-26 $\mu \mathrm{m}$ high, 13-18 $\mu \mathrm{m}$ in diam; middle and lower cells obconical and subhyaline, frequently curved, wall unequal in height, hence the base of the conidia become curved, schizolytic conidial liberation leaving conidia with a truncated closed base.

\section{Telomorph:}

Not observed.

\section{Comments-}

According to Jones et al. (2014), there are 531 species of mitosporic fungi that had been recorded from freshwater habitats all over the world. In India, studies on freshwater mitosporic fungi (375 sp.) were compiled by Patil et al. (2015) and Borse et al. (2016, 2017). In this paper, we describe and illustrate a new submerged-aquatic mitosporic fungus Bactrodesmium aquatica (Fungi, Ascomcota, Pezizomycotina, Dothideomycetes) which was found on submerged dead decaying herbaceous and woody debris from a freshwater rivers and reservoirs (dams, lakes) in India.

The general characteristics of the present collection fit within the concept of the genus Bactrodesmium Cooke (1883). Sporodochia were observed on the surface of the substrate with the naked eye and it is a very common fungus on submerged dead decaying herbaceous and woody debris in this part of the country. The present fungus partially resembles with B. pyriforme Holubova-Jechova (1972) and B. linderii (Crane \& Shearer) Palm \& Stewart (1982). The present fungus differs from B. pyriforme in having larger sporodochia, broadly pyriform, versicoloured smaller conidia and encountered in freshwater habitat. The present fungus also differs from B. linderii in having compact shining (glistering) sporodochia and broadly pyriform smaller conidia. The characteristic features of the present fungus are compared in following Table-1. Microphotographs, line drawings and description of the present fungus were sent to Prof. K. A. Seifert (Rsearch Scientist, Biodiversity (Mycology and Microbiology), Agriculture and Agri-Food, 960 Carling Avenue, Ottawa, Ontario, K1A 0C6, Canada) for identification. He wrote: "Definitely close to Bactrodesmium. The species I see here in Canada does make little sporodochia like this. B. pyriforme seems very close to your fungus".

Table 1:-Comparison of Bactrodesmium pyriforme and B. linderii with the present fungus.

\begin{tabular}{|l|l|l|l|l|}
\hline Species & Sporodochium & Conidia & Habitat & Source \\
\hline B. pyriforme & $\begin{array}{l}\text { Shining, up to 450 } \\
\text { um diam. }\end{array}$ & $\begin{array}{l}\text { Obovoid to } \\
\text { pyriform, straight, } \\
(21-) 26-30 \mu \mathrm{m} \text { long }\end{array}$ & $\begin{array}{l}\text { Terrestrial on dead } \\
\text { bark }\end{array}$ & $\begin{array}{l}\text { Holubova-Jechova } \\
(1972)\end{array}$ \\
\hline
\end{tabular}




\begin{tabular}{|c|c|c|c|c|}
\hline & & $\begin{array}{l}\text { and }(12.5-) 13-16(- \\
17.5) \mu \mathrm{m} \text { thick at the } \\
\text { broadest point, } 2- \\
\text { septate }\end{array}$ & & \\
\hline B. linderii & Effuse, not-shining & $\begin{array}{l}\text { Subglobose to } \\
\text { obpyriform, } 20-33.6 \\
\times 14.5-20.5 \mu \mathrm{m}, 3- \\
7.5 \mu \mathrm{m} \text { at base, } 1-2- \\
\text { septate }\end{array}$ & $\begin{array}{l}\text { Freshwater, on } \\
\text { submerged Balsa } \\
\text { wood blocks }\end{array}$ & $\begin{array}{l}\text { Crane \& Shearer } \\
\text { (1978) }\end{array}$ \\
\hline B. aquatica & $\begin{array}{l}\text { Compact, shining, } \\
100-500 \mu \mathrm{m} \text { in } \\
\text { diam., surrounded } \\
\text { by } 25-40 \mu \mathrm{m} \text { thick } \\
\text { gelatinous matrix }\end{array}$ & $\begin{array}{l}\text { Broadly pyriform, } \\
\text { curved, smooth, } \\
\text { rounded at the apex, } \\
15-25 \mu \mathrm{m} \text { high, } 10- \\
15 \mu \mathrm{m} \text { diam, } 2- \\
\text { septate }\end{array}$ & $\begin{array}{l}\text { Freshwater on } \\
\text { submerged } \\
\text { herbaceous and } \\
\text { woody debris }\end{array}$ & This paper \\
\hline
\end{tabular}

\section{Acknowledgements:-}

We wish to acknowledge the generous cooperation of Hon'ble authorities of management and Principals of our respective colleges for providing the numerous facilities to enable us to continue the research. We thank to Prof. K. A. Seifert (Biodiversity (Mycology and Microbiology), Agriculture and Agri-Food, Canada) for his comments on microphotographs, line drawing and description of the present fungus. Thank are due to the authorities of Smithsonian Tropical Research Institute, Washington DC, USA for providing pd files of research articles / papers on freshwater fungi.

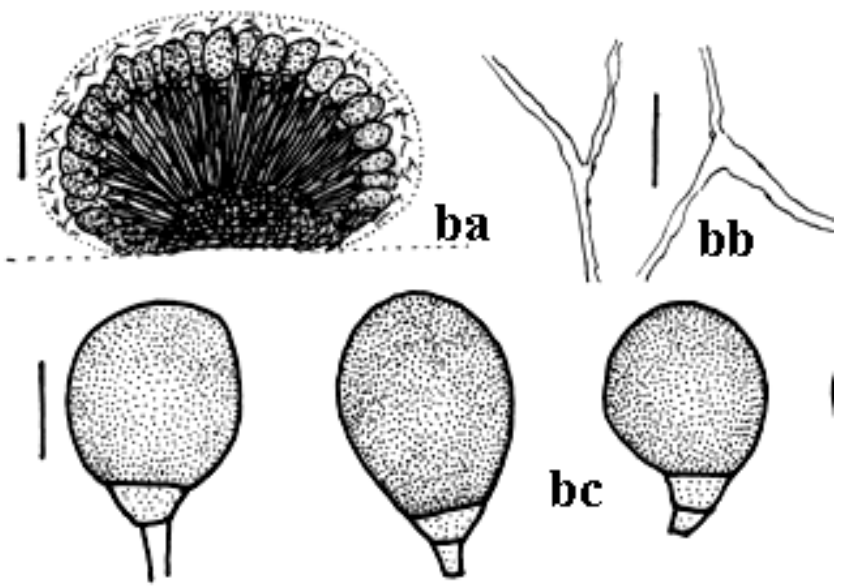

Fig 1:-a- Sporodochium with mucilaginous sheath (arrow), b- sterile hyphae of sporodochium sheath, c- conidia; scale bars $=10 \mu \mathrm{m}$ 

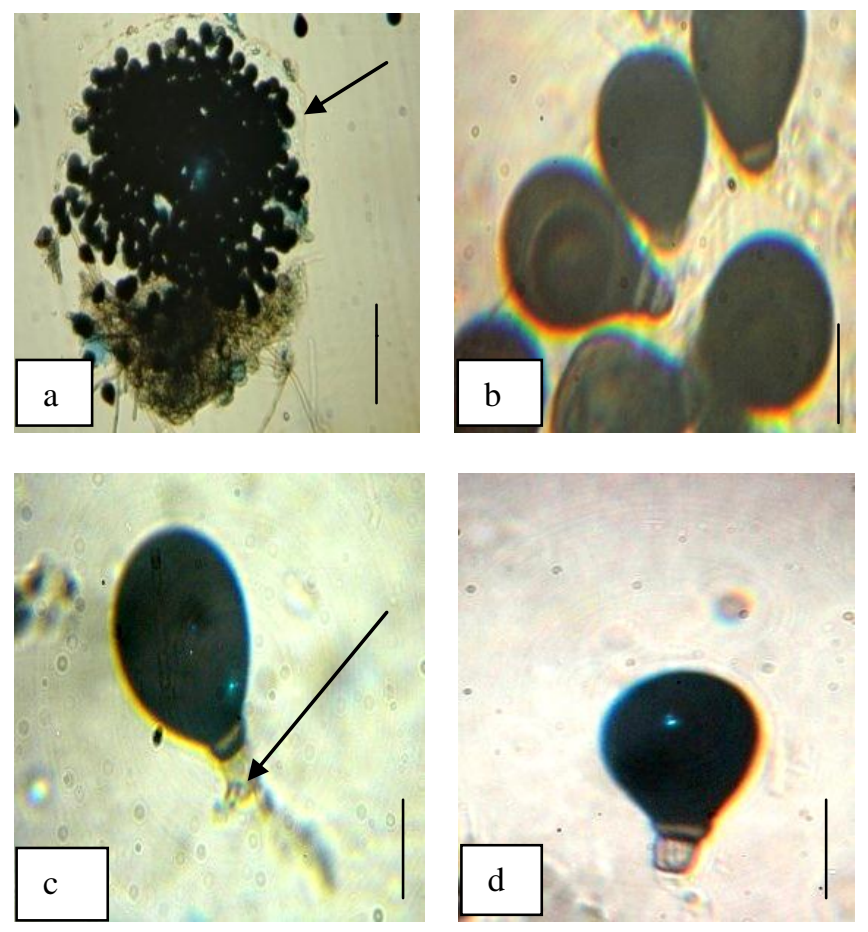

Fig 2:-a. Sporodochium with sheath (arrow), b. Conidia, c. Conidiophore (arrow) with conidium, d. Conidium

\section{Literature cited:-}

1. Borse BD, Borse KN, Patil SY, Pawara CM, Nemade LC, Patil VR. 2016. Freshwater Higher Fungi of India. Lulu Pub., USA. 420 p.

2. Borse BD, Borse KN, Chaudhary SA, Patil VR, Patil SY, Gosavi SA, Borade DS. 2017. Freshwater and Marine Fungi of India. LAP Lambert Academic Publishing, Germany. 162 p.

3. Crane JL, Shearer CA. 1978. Two new species of Trichocladium (Hyphomycetes) from submerged wood. Mycologia 70: 866-874.

4. Cooke MC. 1883. Saccardo’s Sylloge Fungorum. Grevillea 12: 34-35.

5. Goh TK, Hyde KD. 1996. Biodiversity of freshwater fungi. J. Industrial Microbiology 17: 328-345.

6. Goh TK, Tsui CKM. 2003. Key to common dematiaceous hyphomycetes from freshwater. In: Freshwater Mycology (eds. Tsui, C.K.M. Hyde, K.D.), Fungal Diversity Res. Ser., 10, The Fungal Diversity Press, Hong Kong, China, p. 325-343.

7. Holubova-Jechova V. 1972. Lignicolous Hyphomycetes from Czechoslovakia 2. Bactrodesmium. Folia Geobot. Phytota. 7: 407-418.

8. Ingold CT. 1975. An illustrated guide to Aquatic and Water-borne Hyphomycetes (Fungi Imperfect) with notes on their Biology. Freshwater Biol. Asso. Sci, Publications, No. 30, p. 1-96.

9. Jones EBG, Hyde KD, Pang KL (eds.). 2014. Introduction. In: Freshwater Mycology and Fungal-Like Organisms, Walter de Gruyer, GmbH, Berlin, Germany. p. 1-22.

10. Palm ME, Stewart EL. 1982. Two new combinations in Bactrodesmium. Mycotaxon 15: 319-325.

11. Patil VR, Borse BD. 2015. Checklist of freshwater Mitosporic fungi of India. International J. Bioassays 4: 4090-4099.

12. Park D. 1972. On the ecology of heterotrophic Micro-organisms in freshwater. Trans. Br. Mycol. Soc. 58: 291299. 